\title{
The Tanoak Tree: An Environmental History of a Pacific Coast Hardwood. By Frederica Bowcutt. 2015. University of Washington Press, Seattle. 219 pp.
}

\author{
Katherine E. French ${ }^{1^{*}}$ \\ ${ }^{1}$ Department of Plant Sciences, University of Oxford, Oxford, England. \\ *katherine.french@plants.ox.ac.uk
}

Received December 31, 2016

OPEN ठACCESS
DOI $10.14237 / \mathrm{ebl} .8 .1 .2017 .862$

Accepted February 13, 2017

Copyright (c) 2017 by the author(s) licensee Society of Ethnobiology. This is an open-access article distributed under the terms of the Creative Commons Attribution-NonCommercial 4.0 International Public License (https://creativecommons.org/licenses/by-nc/4.0), which permits non-commercial use, distribution, and reproduction in any medium, provided the original author and source are credited.

From new medicines to new materials, plants that have been valued historically are now being repurposed for the demands of twenty-first century life. Applied ethnobiology plays a strong role in this process by highlighting how specific plants were used in the past and how they can be used and sustainably managed in the future. Frederica Bowcutt's book, The Tanoak Tree: An Environmental History of a Pacific Coast Hardwood, focuses on the cultural and environmental history of an indigenous American tree in an effort to reinvigorate the socio-economic use of the tanoak (Notholithocarpus densiflorus) in the face of rapid decline. Tanoak is the only species in the Notholithocarpus genus and is native to the western coast of the United States (Oregon to California). Tanoaks have a checkered past, with population levels rising and falling in parallel with human exploitation. Before colonial times, indigenous groups valued tanoaks as a source of food and used fire to sustainably manage forest productivity and pathogens. In the nineteenth century, tanoak acorns became a prized source of livestock feed for American settlers due to their high protein, fat, carbohydrate and tannin content. Tanoak bark also became a cornerstone of emerging tanning industries. At the same time, native communities began clearing tanoaks to graze livestock. These processes greatly reduced tanoak populations, leading to calls by the US Forest Service and Californian Department of Agriculture in the late nineteenth and twentieth century to reduce over-exploitation. By the twentieth century, tanoaks fell out of economic use and foresters felled these hardwoods in favor of softwoods. Today, the tree faces extinction due to pathogens and climate change.
Bowcutt's book demonstrates how ethnobiology can call attention to at-risk species and can reinvigorate the sustainable use of indigenous plants. For example, current livestock production systems in the United States could re-adopt feeding livestock acorns. Tannins have strong anti-parasitic properties and could reduce anthelmintic use in commercial livestock production systems (Piluzza et al. 2014). Indigenous communities (and perhaps entrepreneurs) could produce specialty flours and other products made from tanoak acorns based on traditional processing techniques of the Karuk people. These traditions date back 6,000 years and involve soaking, fermenting or grinding the acorns to remove the bitter tannins. Although some might question the ethics of using traditional knowledge for commercial gain (particularly by non-indigenous communities) an agreement could be established to funnel part of the financial gain from these products back into local communities and tanoak conservation.

The Tanoak Tree also calls attention to the potential ecological and economic effects of losing cultural keystone species. Cultural keystone species are those which have a strong cultural and ecological role within a given society in a specific geographic area (Garibaldi and Turner 2004). Currently, "sudden oak death" (Phytophthora ramorum) is rapidly reducing tanoak populations. P. ramorum is a fungus that cuts off the water flow to the tree by blocking xylems, killing trees in weeks. The loss of these trees is devastating to local redwood ecosystems. Bowcutt notes that a number of birds (e.g., Steller's jay, Cyanocitta stellern) and mammals (e.g., American black 
bear, Ursus americanus) consume tanoak acorns. The tree is also host to 265 ecotomycorrhizal fungi, including the American matsuke (Tricholoma magnivelare) which is collected by Californian tribes for consumption and export, all of which could disappear with the loss of tanoak populations. Similar tree diseases (e.g., Dutch Elm disease, Ash dieback) are also increasing in other parts of the world, in part, due to the increased globalization of trade. Loss of any of these tree species can have profound effects that ripples through multiple trophic levels and threatens the provision of many forest ecosystem services (Boyd et al. 2013).

The alarming effect of $P$. ramorum on tanoak populations is a powerful reminder of how traditional conservation measures (restoring populations, preventing over-harvesting) are powerless in the face of microbial pathogens. Bowcott describes several measures currently used (e.g., potassium phosphite, establishing in-situ and ex-situ collections) yet these have had limited success. Hopefully the example of the tanoak will spur more research in developing biocontrol systems for microbial pathogens. Often biocontrol systems are applied to crops (e.g., seed treatments); few treatments exist for trees and even fewer treatments are applied at the ecosystem level. Plants contain thousands of chemicals that can be exploited for this purpose. For example, polyphenols and terpenoids derived from several west-coast conifers (Western redcedar, yellow cedar, Western juniper, and Port Orford cedar) showed in vitro antimicrobial activity against $P$. ramorum and placing woodchips from these species around tanoak trees reduced the abundance of the fungal pathogen (Manter et al. 2007). Future research could look at compounds from other local plants that target fungal virulence mechanisms (e.g., cell-wall proteins secreting effectors, spore production) and how these might be integrated into current landscapes as a form of low-level pathogen control (Meijer et al. 2006). If such biocontrol measures work with tanoaks similar approaches might also be applied to other trees and plants at risk.

Overall, Bowcutt's book is well-researched and integrates ethnography, ecology, and social history. It will surely be of great interest to anthropologists and American economic historians. Numerous photos, diagrams and illustrations enhance the text and give the reader a feel for the cultural landscape of the tanoak. Bowcott's research is an excellent example of how ethnobiology can inform conservation and resource management and will hopefully spur similar 'life histories' of species at risk of extinction.

\section{References Cited}

Boyd, I. L., P. H. Freer-Smith, C. A. Gilligan, and H. C. J. Godfray. 2013. The Consequence of Tree Pests and Diseases for Ecosystem Services. Science 342:1235773.

Garibaldi, A., and N. Turner. 2004. Cultural Keystone Species: Implications for Ecological Conservation and Restoration. Ecology and Society 9:1.

Manter, D. K., R. G. Kelsey, and J. J. Karchesy. 2007. Antimicrobial Activity of Extractable Conifer Heartwood Compounds Toward Phytophthora ramorum. Journal of Chemical Ecology 33:2133-2147.

Meijer, H. J. G., P. J. I. van de Vondervoort, Q. Y. Yin, C. G. de Koster, F. M. Klis, F. Govers, and P. W. J. de Groot. 2006. Identification of Cell WallAssociated Proteins from Phytophthora ramorum. Molecular Plant-Microbe Interactions 19:1348-1358.

Piluzza, G., L. Sulas, and S. Bullitta. 2014. Tannins in Forage Plants and Their Role in Animal Husbandry and Environmental Sustainability: A Review. Grass and Forage Science 69:32-48. 